\title{
Cloning of genes required for amino acid biosynthesis from Leptospira interrogans serovar icterohaemorrhagiae
}

\author{
Catherine Richaud, Danielle Margarita, Guy Baranton and Isabelle Saint Girons*
}

Unité des Leptospires, Institut Pasteur, 75724 Paris Cedex 15, France

(Received 17 October 1989; revised 2 January 1990; accepted 10 January 1990)

\begin{abstract}
Leptospira interrogans belongs to a large family of important pathogens, which is part of the order Spirochaetales, a distinct group of eubacteria. In order to obtain a better understanding of the genetic organization of this species, we have constructed a DNA library of the serovar icterohaemorrhagiae, using the Escherichia coli vector pUC13. We have isolated Leptospira DNA fragments containing the genetic information required to complement strains of $E$. coli with defects in proline and leucine biosynthesis. While a $3.9 \mathrm{~kb}$ fragment which complemented proA also complemented proB, a $15 \mathrm{~kb}$ fragment complementing leuB could not complement other leu mutations. The $L$. interrogans origin of the cloned DNA fragments was confirmed by DNA-DNA hybridization. The hybridization was specific to the pathogenic species and was not seen with the saprophytic species $L$. biflexa.
\end{abstract}

\section{Introduction}

Leptospira, a member of the order Spirochaetales, is a genus composed of thin, motile, aerobic, spiral-shaped bacteria (Johnson, 1977). The two species, L interrogans, which is pathogenic for man and animals, and L. biflexa, which is saprophytic, contain many different serovars. 16S rRNA phylogenetic studies suggest that the spirochaetes represent a group of eubacteria of ancient origin (Paster et al., 1984). Leptospira has simple nutritional requirements. The only necessary organic compounds are vitamins B12 and B1, and long-chain fatty acids, which serve as the obligate carbon and energy sources (Johnson \& Gary, 1962; Johnson et al., 1969).

Radiotracer studies (Charon et al., 1974) similar to those done on Escherichia coli (Roberts et al., 1955) indicate that the known biosynthetic pathways for amino acids are used in Leptospira. One exception is that isoleucine is not exclusively derived from threonine (Charon et al., 1974; Westfall et al., 1983). Studies on the organization and regulation of the amino acid biosynthetic genes in Leptospira are still in their infancy. Feedback inhibition of anthranilate synthase and threonine deaminase by tryptophan and isoleucine respectively has been demonstrated (Yelton \& Peng, 1989; Westfall, 1980). No support for any mechanism of regulation at the level of gene expression (by repression or attenuation, for example) has been given. Three biosynthetic genes $(\arg E, \operatorname{trp} G$ and $\operatorname{trp} E$ ) from the non-pathogenic species $L$. biflexa were cloned by complementation of the corre- sponding $E$. coli mutants and then sequenced (Zuerner \& Charon, 1988; Yelton \& Charon, 1984; Yelton \& Cohen, 1986). The trpE gene from Spirochaeta aurantia, which also belongs to the order Spirochaetales, has also been cloned (Brahamsha \& Greenberg, 1987).

Since Leptospira has a unique morphology, physiology and evolutionary peculiarity, we were interested in its genetics. Here we report the cloning of $L$. interrogans genes which complemented mutations in the pro $A$, proB and $l e u B$ genes of $E$. coli. Similarities and differences in their organization relative to the corresponding $E$. coli genes are discussed.

\section{Methods}

Bacterial strains, plasmids and media. Escherichia coli strains and plasmids are listed in Table 1. E. coli strains were grown in Luria broth in liquid or $0.75 \%$ agar (Miller, 1972). The following Leptospira strains (national reference centre, France) were used: L. interrogans serovar icterohaemorrhagiae strain Verdun and L. biflexa serovar patoc strain Patoc 1. Minimal 63 medium (Miller, 1972) supplemented with $0.2 \%$ glucose, $50 \mu \mathrm{g}$ ampicillin $\mathrm{ml}^{-1}$ and $1 \mu \mathrm{g}$ thiamin $\mathrm{ml}^{-1}$ was used to characterize $E$. coli transformants; the medium allowing selection for $\mathrm{Pro}^{+}$and $\mathrm{Leu}^{+}$transformants additionally contains leucine and proline at concentrations of $2 \mathrm{mM}$. Leptospira strains were grown in EMJH medium (Ellinghausen \& McCullough, 1965; Johnson \& Harris, 1967). Borrelia burgdorferi strain B31 was grown in BSKII medium (Barbour, 1984).

Recombinant DNA techniques. Leptospira chromosomal DNA was isolated by the method of Silhavy et al. (1984). Restriction enzyme digests, ligations, agarose gel electrophoresis, and small-scale plasmid isolations were by standard procedures (Maniatis et al., 1982). The 
Table 1. E. coli strains and plasmids

\begin{tabular}{|c|c|c|}
\hline & Relevant genotype & Source or reference \\
\hline \multicolumn{3}{|c|}{ E. coli strains } \\
\hline GT869 & 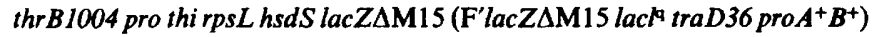 & Parsot (1986) \\
\hline HB101 & $\begin{array}{l}\mathrm{F}^{-} \text {hsdS recA13 ara-14 proA2 leuB6 lacYl galK2 rpsL20 xyl-15 mtl-1 } \\
\text { supE44 } \lambda\end{array}$ & $\underset{(1969)}{\text { Boyer } \& \text { Roulland-Dussoix }}$ \\
\hline AR1062 & thr leu lac gal xyl mal mtl min hsdS & Rambach \& Hogness (1977) \\
\hline JM83 & ara $\Delta($ lac-pro $)$ rpsL thi $\phi 80 \mathrm{~d} l a c Z \Delta \mathrm{M} 15$ & Vieira \& Messing (1982) \\
\hline $\mathrm{X} 340$ & proB 28 metB1 relA1 spoT1 $\lambda^{-}$ & B. Bachmann (Yale University) \\
\hline DJ105 & $\mathrm{F}^{-}$leu proC trp his ilv argH purD met ara lac mal gal str & J. H. Miller (Los Angeles, USÄ) \\
\hline CV512 & $\mathrm{F}^{+}$leuA321 & \\
\hline CV514 & $\mathrm{F}^{+}$leuB401 & \\
\hline CV516 & $\mathrm{F}^{+}$leuB061 & \\
\hline CV 520 & $\mathrm{~F}^{+} l e u C 17 I$ & I. M. Calvo (Ithaca, NY, USA) \\
\hline CV522 & $\mathrm{F}^{+}$leuC222 & \\
\hline CV524 & $\mathrm{F}^{+} l e u D 211$ & \\
\hline CV526 & $\mathrm{F}+$ leuD101 & \\
\hline $\mathrm{MCl061}$ & araD139 $\triangle($ ara, leu $) 7697 \Delta l a c X 74$ galU galK hsdR rpsL & Casadaban \& Cohen (1980) \\
\hline \multicolumn{3}{|l|}{ Plasmids } \\
\hline pUC9 & $A_{p^{R}}$ & Vieira \& Messing (1982) \\
\hline pUC13 & $A^{R}$ & Messing (1983) \\
\hline pSKS114 & $\mathrm{Ap}^{R} \mathrm{Cm}^{\mathrm{R}}$ & Shapira et al. (1983) \\
\hline
\end{tabular}

method of Hanahan (1983) was used for $E$. coli transformation. Ap ${ }^{r}$ transformants were selected at $37^{\circ} \mathrm{C}$ on plates containing $50 \mu \mathrm{g}$ ampicillin $\mathrm{ml}^{-1}, 20 \mu \mathrm{g}$ 5-bromo-4-chloro-3-indolyl- $\beta$-D-galactopyranoside $\mathrm{ml}^{-1}$ and $5 \mathrm{~mm}$-isopropyl thiogalactopyranoside. DNA from $L$. interrogans was partially digested with restriction endonuclease BamHI and mixed with an approximately equimolar amount of pUC13. The pUC13 DNA was purchased from Pharmacia, already digested to completion with BamHI and dephosphorylated. The DNA mixture was incubated with T4 DNA ligase for $18 \mathrm{~h}$ at $4{ }^{\circ} \mathrm{C}$. The entire ligation mixture $(0.5 \mu \mathrm{g}$ of total DNA) was used to transform $E$. coli strain GT869. By use of this procedure, a total of 8000 transformants (i.e. 30 transformants per ng of vector DNA) were obtained, $75 \%$ of which contained inserts with an average size of $8-9 \mathrm{~kb}$. Total plasmid DNA was extracted from the pool of $\mathrm{Ap}^{r}$ transformants by the alkaline method of Birnboim \& Doly (1979) (adjusted for a large amount of cells) with a recovery of $5 \mathrm{mg}$ of plasmid DNA.

DNA-DNA hybridizations. For blot analysis according to Southern (1975), DNA was transferred to a nylon membrane. Probes were radiolabelled with $\left.{ }^{35} \mathrm{~S}\right] \mathrm{dCTP}\left(37 \mathrm{TBq} \mathrm{mmol}^{-1}\right)$ by the multiprime method (Feinberg \& Vogelstein, 1983). Labelled DNA (50 ng) was added to the filter and allowed to hybridize at $65^{\circ} \mathrm{C}$ for $18 \mathrm{~h}$. The filter was washed at $65^{\circ} \mathrm{C}$ in $6 \times \mathrm{SSC}$ then $2 \times \mathrm{SSC}$, air dried and exposed to $\mathrm{X}$-ray film (Kodak X-Omat AR2) for $48 \mathrm{~h}$ at $-80^{\circ} \mathrm{C}(1 \times \mathrm{SSC}$ is $0.15 \mathrm{M}-\mathrm{NaCl}, 0.015 \mathrm{M}$-trisodium citrate, $\mathrm{pH} 7 \cdot 0$ ).

\section{Results}

A colony bank of 8000 individual $\mathrm{Ap}^{\mathrm{r}}$ transformants in E. coli strain GT869 was obtained from $L$. interrogans serovar icterohaemorrhagiae using the $E$. coli multicopy vector $\mathrm{pUC13}$. The serovar corresponds to one used in France to prepare human vaccine.

\section{Cloning of Leptospira interrogans genes encoding proA- and leuB-complementing activities}

A sample $(1 \mu \mathrm{g})$ of total plasmid DNA isolated from the clone bank was used to transform $E$. coli $\mathrm{HB101}$, which carries mutations in the pro $A$ and $l e u B$ genes. About $10000 \mathrm{Ap}^{\mathrm{r}}$ transformants were obtained on $\mathrm{LB}$ rich medium. These clones were then screened by direct replica plating on synthetic medium allowing selection for $\mathrm{Pro}^{+}$or $\mathrm{Leu}^{+}$. Twenty $\mathrm{Pro}^{+}$clones $(0.2 \%)$ and five $\mathrm{Leu}^{+}(0.05 \%)$ were thus obtained. Ten $\mathrm{Pro}^{+}$and the five $\mathrm{Leu}^{+}$clones were studied further.

The plasmid DNA of the $10 \mathrm{Pro}^{+}$and five $\mathrm{Leu}^{+}$clones was analysed by agarose gel electrophoresis after BamHI digestion (Fig. 1). The Pro ${ }^{+}$plasmids (pPL1 and pPL4) and the Leu ${ }^{+}$plasmids ( $\mathrm{pLL1}$ ) contained inserts of 6.4 and $15 \mathrm{~kb}$ respectively. EcoRI restriction enzyme analysis of all these plasmids gave two patterns corresponding to both orientations for the inserts present in the $\mathrm{Pro}^{+}$plasmids, indicating possible expression from Leptospira promoters or from Leptospira sequences functioning as such in $E$. coli; however, in the case of the five $\mathrm{Leu}^{+}$plasmids, only one EcoRI pattern was obtained, indicative of a unique orientation of the $15 \mathrm{~kb}$ BamHI insert (see below).

To determine whether the acquired characters were plasmid-borne, the $\mathrm{Pro}^{+}$and $\mathrm{Leu}^{+}$plasmids were used to transform $E$. coli $\mathrm{HB} 101$ selecting for ampicillin resistance. The clones obtained were then screened for proline or leucine independence: all the $\mathrm{Ap}^{\mathrm{r}}$ transformants obtained with pPL1 and pPL4 were simultaneously $\mathrm{Pro}^{+}$and all those obtained with pLLl were simultaneously $\mathrm{Leu}^{+}$. These results confirm that complementing activities are associated with the recombinant plasmids.

In order to localize the proA and the leuB genes more precisely on the corresponding plasmids and to reduce the Leptospira DNA fragment, different subclonings were performed in each case as described in Fig. 1. These reductions resulted in the following plasmids: pPL11 
(a) pLLI
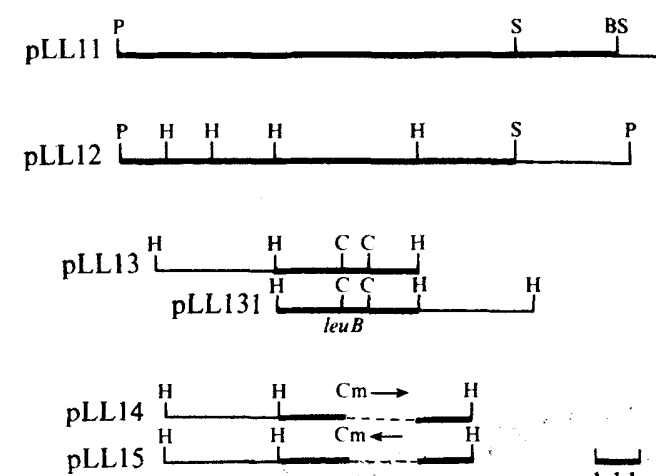

pLL15

(b)

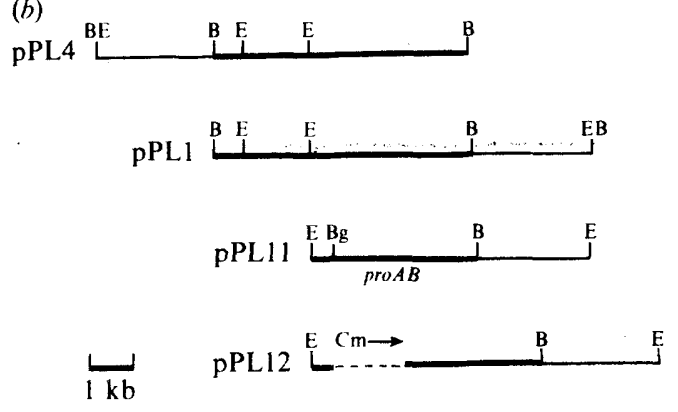

Fig. 1. Subclone analysis of $\mathrm{Pro}^{+}$and $\mathrm{Leu}^{+}$plasmids. (a) Restriction map of leuB-complementing plasmids. pLL1 was isolated from the $L$. interrogans genomic library. Elimination of two PstI fragments gave rise to pLL11. Subsequent elimination of a $2.5 \mathrm{~kb} \mathrm{Sacl}$ fragment gave rise to pLL12. Subcloning of a HindIII fragment from pLL12 into the corresponding site of pUC9 generated pLL13. pLL131 was obtained by HindIII digestion and religation of pLL13 in order to reverse the orientation of the insert. pLL14 and pLL15 were obtained by inserting into Clal-digested pLL13 a $\mathrm{Cm}^{\mathrm{r}}$ 'cassette' from AccI-digested pSKS114, creating at the same time a $0.5 \mathrm{~kb}$ deletion in the Leptospira insert. (b) Restriction maps of proA/B-complementing plasmids. pPL1 and pPL4 were isolated from the $L$. interrogans genomic library. Total digestion of pPLI with EcoRI and self-ligation of the large EcoRIEcoRI fragment obtained gave rise to pPL11. pLL12 was obtained by insertion of the $\mathrm{Cm}^{\mathrm{r}}$ 'cassette' of BamHI-digested pSKS114 into the unique $B g / I I$ site of pPL11. Thin and heavy lines represent pUC vectors and Leptospira DNA inserts respectively; dashed lines represent the $\mathrm{Cm}^{\mathrm{r}}$ 'cassette' from pSKS114. B, BamHI; Bg, BglII; C, ClaI; E, EcoRI; P, PstI; H, HindIII; S, SacI.

carrying a $3.9 \mathrm{~kb}$ Eco RI-BamHI fragment complementing the proA 2 allele and plasmid pLL13 carrying a $3.2 \mathrm{~kb}$ HindIII fragment complementing the leuB6 allele. The orientation of the HindIII insert of pLL13 (Fig. 1a) has been reversed and the resulting plasmid (pLL131) still complements the leuB mutant, suggesting an expression of the gene from Leptospira DNA as was the case for the proline gene.

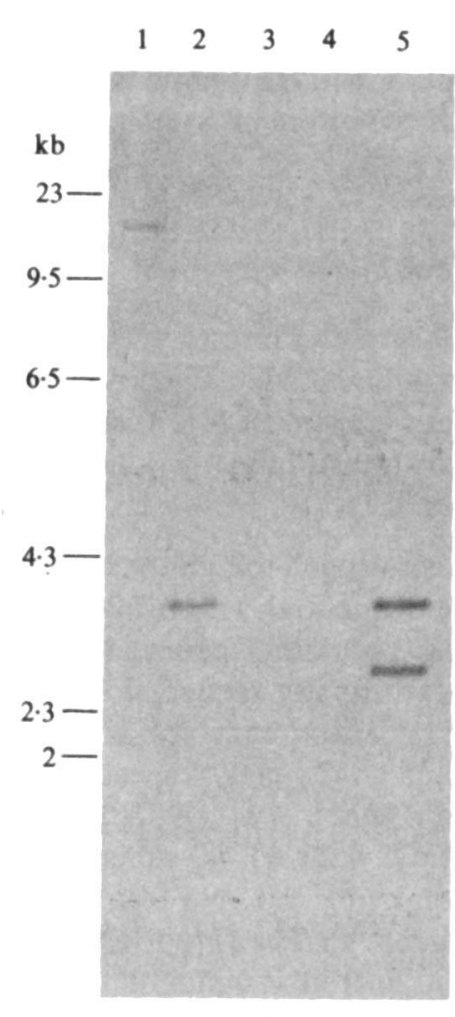

A

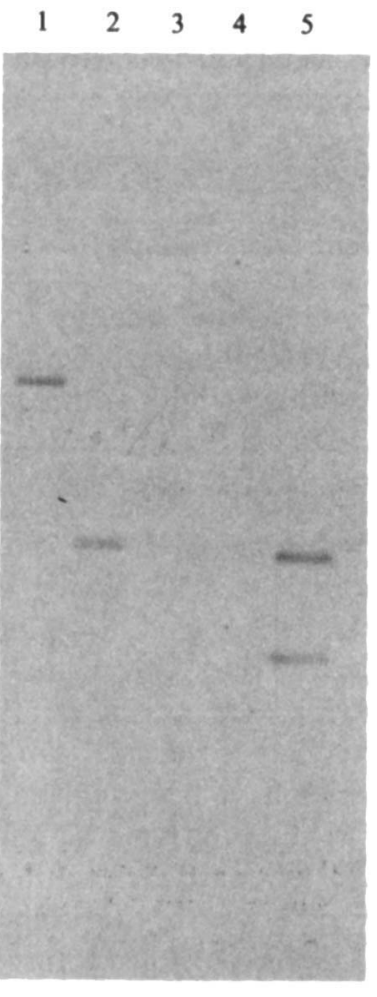

B
Fig. 2. Southern blot analysis of $\mathrm{Leu}^{+}$and $\mathrm{Pro}^{+}$recombinant plasmids (part A and part B, respectively) and chromosomal DNAs from different bacterial sources. Unlabelled chromosomal and plasmid DNAs were digested with restriction enzymes and electrophoresed through a $0.7 \%(w / v)$ agarose gel, denatured and transferred to a nylon membrane. Hybridizations were performed at $65^{\circ} \mathrm{C}$ with $50 \mathrm{ng}$ of labelled pLL13 (A) or pPL11 (B) as probes. Part A: $5 \mu \mathrm{g}$ of $L$. interrogans DNA digested with BamHI (lane 1) or HindIII (lane 2); $5 \mu \mathrm{g}$ of $B$. burgdorferi (lane 3) and $E$. coli (lane 4) DNA digested with HindIII; 10 ng of pLL13 digested with HindIII (lane 5). Part B : $5 \mu \mathrm{g}$ of L. interrogans DNA digested with BamHI (lane 1) or BamHI + EcoRI (lane 2); $5 \mu \mathrm{g}$ of $B$. burgdorferi (lane 3) and $E$. coli (lane 4) DNA digested with $B a m \mathrm{HI}+E c o$ RI; $10 \mathrm{ng}$ of pPL11 digested with $B a m \mathrm{HI}+E c o$ RI (lane 5).

\section{Leptospira origin of cloned fragments}

Hybridization analysis according to Southern (1975) was used to demonstrate that the DNA inserts of the $\mathrm{Pro}^{+}$ and $\mathrm{Leu}^{+}$recombinant plasmids originated from $L$. interrogans. As can be seen from Fig. 2, pPLl1 used as a probe hybridizes with a $6.4 \mathrm{~kb}$ BamHI fragment (lane B1) and a $3.9 \mathrm{~kb} \cdot E c o \mathrm{RI}-$ BamHI fragment (lane B2); pLL13 when used as a probe hybridizes with a $15 \mathrm{~kb}$ BamHI fragment (lane Al) and a $3.2 \mathrm{~kb}$ HindIII fragment (lane A2) of $L$. interrogans chromosomal DNA. These results indicate that no rearrangement occurred during the cloning experiment. Hybridization is seen only with the L. interrogans serovar icterohaemorrhagiae DNA and neither with $E$. coli nor with Borrelia DNA. 
Furthermore, no hybridization is seen with the saprophytic species L. biflexa (data not shown). This indicates that the cloned complementing DNAs were of $L$. interrogans origin.

\section{Gene organization of the cloned fragments}

To determine whether the Leptospira inserts present in the recombinant plasmids could encode genes complementing activities other than proA and $l e u B$, we used the corresponding plasmids to transform other mutant strains of $E$. coli.

Proline genes. In E. coli, conversion of glutamate to proline is mediated by the sequential action of three enzymes: $\gamma$-glutamyl kinase, $\gamma$-glutamyl phosphate reductase and $\Delta$-pyrroline-5-carboxylate reductase (for a review, see Leisinger, 1987). These enzymes are the products of the proB, pro $A$ and proC genes, respectively, which have been sequenced (Deutch et al., 1982, 1984). The first enzyme ( $\gamma$-glutamyl kinase) is subject to allosteric feedback inhibition by proline. No regulation by repression of the proline genes has been reported. The proB and pro $A$ genes form an operon at $6 \mathrm{~min}$ on the $E$. coli chromosome while the proC gene is unlinked at 9 min.

Besides strain HB101, several proline auxotrophs were transformed with plasmids pPL1, pPL4 and pPL11: strain JM83, which is deleted for both proB and proA genes, strain X340 which carries a proB mutation and strain DJ105 which carries a proC mutation. The transformants were then assayed for growth in the absence of proline. Strains JM83 and X340 were complemented by all recombinant plasmids while DJ 105 was complemented by none of them; i.e. the $3.9 \mathrm{~kb}$ of Leptospira DNA encodes both proB and proA activities but proC, if present, is not expressed. In $E$. coli, a $2.5 \mathrm{~kb}$ fragment is sufficient to encode the entire proBA locus (Deutch et al., 1984). This would suggest a genetic linkage in Leptospira similar to that in E. coli.

To examine whether Leptospira proB and proA genes were organized in an operon as in $E$. coli, we inserted a chloramphenicol-resistance 'cassette' in the Leptospira insert of pPL11 (see details of the constructs in the legend of Fig. 1). The resulting plasmid, pPL12, no longer complemented the different proA,B E. coli strains: this result suggests that insertion of the 'cassette' is polar and that Leptospira proB and pro $A$ genes constitute an operon. However, further data are necessary to demonstrate that the pro $A$ and proB genes form a single transcriptional unit with two distinct translational products.

The leuB gene. The oxidative decarboxylation of $\beta$ isopropylmalate is the penultimate reaction in the leucine biosynthetic pathway in $E$. coli as well as in other micro-organisms (reviewed by Umbarger, 1987). The enzyme $\beta$-isopropylmalate dehydrogenase (LeuB) which catalyses this reaction, together with the two other enzymes, isopropylmalate synthetase (LeuA) and isopropylmalate isomerase (LeuCD), which are specifically involved in L-leucine biosynthesis are the products of an operon, leuABCD, which is subject to regulation by attenuation. Only the nucleotide sequence of the leuD gene has been reported (Friedberg et al., 1985).

In order to examine whether the Leptospira leu genes were also contiguous, we transformed several leucine auxotrophs mutated in leuA (CV512), leuC (CV520 and CV522) or leuD (CV524 and CV526) as well as a strain (MC1061) deleted for the whole leucine operon with plasmids pLL1 ( $15 \mathrm{~kb}$ insert), pLL13 and pLL131 ( $3.2 \mathrm{~kb}$ insert). None of the recombinant plasmids complemented any of the defined mutations tested.

\section{Discussion}

Few DNA sequences from the pathogenic species $L$. interrogans have been cloned and maintained in $E$. coli: DNA probes usable in taxonomic identification (LeFebvre, 1987; Van Eys et al., 1988; Zuerner \& Bolin, 1988) isolated from serovar hardjo colony libraries; antigen genes from a serovar canicola colony library (Yamaguchi et al., 1988); two antigen genes from serovar pomona (Doherty et al., 1989); and a 23S ribosomal RNA gene from serovar canicola (Fukunaga et al., 1989).

This paper reports the first cloning of genes involved in amino acid biosynthetic pathways from a pathogenic Leptospira strain. As already mentioned, such genes (involved in tryptophan and arginine biosynthesis) have been isolated from a saprophytic species of Leptospira (Yelton \& Charon, 1984; Zuerner \& Charon, 1988). Our results of DNA hybridization are in agreement with those of these authors in indicating a genetic divergence between the pathogenic and saprophytic species of Leptospira, a divergence previously noted by Brendle $e t$ al. (1974).

The $L$. interrogans DNA clone bank constructed here seems to be representative. The E. coli strain (HB101) used for cloning the biosynthetic genes is auxotrophic for leucine and proline, and Leptospira genes encoding both complementing activities were cloned. Indeed, assuming that the size of the Leptospira genome is around $5000 \mathrm{~kb}$, (C. Baril \& I. Saint Girons, unpublished results) and that the average size of the inserts is $8 \mathrm{~kb}$, our DNA clone bank represents 10 times the genome.

The Leptospira gene which complements the E. coli leuB allele is most likely the structural gene for 
isopropylmalate dehydrogenase since the cloned gene complements three different alleles of the leuB gene (strains HB101, CV514 and CV516). The positive complementation of more than one allele is crucial. For example, instead of the actual leuB structural gene, an allele-specific suppressor of the leuB6 mutation present in HB101 has been cloned from Lactobacillus bulgaricus (Hottinger et al., 1987). No other Leptospira leucine gene was cloned, although the leuB gene is located in the middle of the insert and the size of the insert is large enough $(15 \mathrm{~kb})$ to encode several genes. Different explanations for these results are possible. The other Leptospira leucine genes could be unlinked to the leuB gene, which would indicate an organization different to that found in E. coli and in Bacillus subtilis (Piggot \& Hoch, 1985), where the leucine biosynthetic genes form an operon. These leucine genes could also be present on the plasmid but not expressed in $E$. coli.

The Leptospira genes encoding proline-complementing activity consist of two genes, $\operatorname{proB}$ and $\operatorname{pro} A$. A fragment of $3.9 \mathrm{~kb}$ is sufficient to encode these two activities. In $E$. coli, the pro $B$ and pro $A$ genes are organized as an operon proBA on a $2.5 \mathrm{~kb}$ DNA fragment (Deutch et al., 1984). Our data suggest that in Leptospira, the pro $B$ and pro $A$ genes could also be organized as an operon, although other possibilities such as for example a single gene encoding a bifunctional protein are not ruled out. The linkage of the proA and pro $B$ genes in organisms such as $E$. coli, Salmonella typhimurium (Sanderson \& Roth, 1988) Campylobacter (Lee et al., 1985) and Leptospira is perhaps related to the fact that $\gamma$-glutamyl kinase (proB product) is active only in association with $\gamma$-glutamyl phosphate reductase ( $p r o A$ product), the second enzyme of the proline biosynthetic pathway (Smith et al., 1984). However, the situation is different for Pseudomonas and Saccharomyces (Adams \& Frank, 1980), where the three proline genes, $A, B$ and $C$, are scattered.

In conclusion, our experiments show that $L$. interrogans amino acid biosynthetic genes can be expressed in E. coli. Attempts to identify the proteins derived from the cloned Leptospira genes (intact or inactivated by a chloramphenicol cassette) by minicell analysis failed. The products of the leuB, pro $A$ and $p r o B$ genes, although expressed at a level sufficient for complementation of the corresponding $E$. coli mutants, are not visible as distinct bands on a gel. Expression has already been demonstrated for genes from the saprophytic species L. biflexa, although in none of these cases has any evidence been given that this expression occurs from Leptospira signals. These cloned genes are useful material for genomic mapping and the chloramphenicol insertions in these genes are powerful tools for obtaining mutations on the Leptospira chromosome.
We would like to thank Iain Old and Philippe Marlière for critical reading of the manuscript, and Pascale Amouriaux and Yvette Dufresne for the Leptospira and Borrelia cultures. This work was supported by the Pasteur Institute, the Centre National de la Recherche Scientifique (UA 1129), and the Institut National de la Santé et de la Recherche Médicale (883013). We wish to thank Lucile Girardot for assistance in typing the table and typesetting.

\section{References}

ADAMS, E. \& FranK, L. (1980). Metabolism of proline and the hydroxyprolines. Annual Review of Biochemistry 49, 1005-1061.

BARBOUR, A. G. (1984). Isolation and cultivation of Lyme disease spirochetes. Yale Journal of Biological Medicine 57, 521-555.

BIRNBOIM, H. C. \& DolY, J. (1979). A rapid alkaline extraction procedure for screening recombinant plasmid DNA. Nucleic Acids Research 7, 1513-1523.

BOYER, A. W. \& Roulland-Dussorx, D. (1969). A complementation analysis of the restriction and modification of DNA in Escherichia coli. Journal of Molecular Biology 41, 459-472.

Brahamsha, B. \& GreEnberg, E. P. (1987). Complementation of a trpE deletion in Escherichia coli by Spirochaeta aurantia DNA encoding anthranilate synthetase component I activity. Journal of Bacteriology 169, 3764-3679.

Brendle, J. J., Rogul, M. \& Alexander, A. D. (1974). Deoxyribonucleic acid hybridization among selected leptospiral serotypes. International Journal of Systematic Bacteriology 24, 205-214.

Casabadan, M. J. \& Cohen, S. N. (1980). Analysis of gene control signals by DNA fusion and cloning in Escherichia coli. Journal of Molecular Biology 138, 179-207.

Charon, N. W., Johnson, R. C. \& Peterson, D. (1974). Amino acid biosynthesis in the spirochete Leptospira: evidence for a novel pathway of isoleucine synthesis. Journal of Bacteriology 117, 203-211.

DeUtCH, A. H., SMITH, C. J., Rushlow, K. E. \& KRETSChMeR, P. J. (1982). Escherichia coli $\Delta^{1}$-pyrroline-5-carboxylate reductase: gene sequence, protein overproduction and purification. Nucleic Acids Research 10, 7701-7714.

Deutch, A. H., Rushlow, K. E. \& SMith, C. J. (1984). Analysis of the Escherichia coli proBA locus by DNA and protein sequencing. Nucleic Acids Research 12, 6337-6354.

Doherty, J. P., Adler, B., Rood, J. I., Billington, S. J. \& Faine, S. (1989). Expression of two conserved leptospiral antigens in Escherichia coli. Journal of Medical Microbiology 28, 143-149.

Ellinghausen, H. C. \& McCullough, W. G. (1965). Nutrition of Leptospira pomona and growth of 13 other serotypes: fractionation of oleic albumin complex and a medium of bovine albumin and polysorbate 80. American Journal of Veterinarian Research 26, 45-51.

Feinberg, A. P. \& Vogelstein, B. (1983). A technique for radiolabelling DNA restriction endonuclease fragments to high specific activity. Analytical Biochemistry 132, 6-13.

Friedrerg, D., Rosenthal, E. R., Jones, J. W. \& Calvo, J. M. (1985). Characterization of the $3^{\prime}$ end of the leucine operon of Salmonella typhimurium. Molecular and General Genetics 199, 486-494.

FUKUNAGA, M., HoRIE, I. \& MifUCHI, I. (1989). Nucleotide sequence of a 23S ribosomal RNA gene from Leptospira interrogans serovar canicola strain Moulton. Nucleic Acids Research 17, 2123.

Hanahan, D. (1983). Studies on transformation of Escherichia coli with plasmids. Journal of Molecular Biology 166, 557-580.

Hottinger, H., Ohgi, T., Zwahlen, M. C., Dhamija, S. \& Sôll, D. (1987). Allele-specific complementation of an Escherichia coli leuB mutation by a Lactobacilus bulgaricus tRNA gene. Gene 60, 75-83.

Jornson, R. C. (1977). The spirochetes. Annual Review of Microbiology 31, 89-106.

JOHNSON, R. C. \& GARY, N. D. (1962). Nutrition of Leptospira pomona. II. Fatty acid requirements. Journal of Bacteriology 85, 976-982.

Johnson, R. C. \& HARRIS, V. G. (1967). Differentiation of pathogenic and saprophytic Leptospires: growth at low temperatures. Journal of Bacteriology 94, 27-31. 
Johnson, R. C., Harris, V. G. \& WalbY, J. K. (1969). Characterization of leptospires according to their fatty acid requirements. Journal of General Microbiology 55, 399-407.

LeE, E. C., Walker, R. I. \& Guerry, P. (1985). Expression of Campylobacter genes for proline biosynthesis in Escherichia coli. Canadian Journal of Microbiology 31, 1064-1067.

LEFEBVRE, R. B. (1987). DNA probe for detection of the Leptospira interrogans serovar hardjo genotype hardjo-bovis. Journal of Clinical Microbiology 25, 2336-2338.

LEISINGER. T. (1987). Biosynthesis of proline. In Escherichia coli and Salmonella typhimurium: Cellular and Molecular Biology, pp. 345351. Edited by F. C. Neidhardt, J. L. Ingraham, K. B. Low, B. Magasanik, M. Schaechter \& H. E. Umbarger. Washington, DC: American Society for Microbiology.

Maniatis, T., Fritsch, E. F. \& Sambrook, J. (1982). Molecular Cloning: a Laboratory Manual. Cold Spring Harbor, NY: Cold Spring Harbor Laboratory.

Messing, J. (1983). New M13 vectors for cloning. Methods in Enzymology. 101C, 20-78.

MilleR, J. H. (1972). Experiments in Molecular Genetics. Cold Spring Harbor, NY: Cold Spring Harbor Laboratory.

PARSOT, C. (1986). Evolution of biosynthetic pathways: a common ancestor for threonine synthase, threonine dehydratase and $D$-serine dehydratase. EMBO Journal 5, 3013-3019.

Paster, B. J., Stackebrandt, E., Hespell, R. B., Hahn, C. M. \& WOESE, C. R. (1984). The phylogeny of the spirochetes. Systematic and Applied Microbiology 5, 337-351.

Piggot, P. J. \& Hoch, J. A. (1985). Revised genetic linkage map of Bacillus subtilis. Microbiological Reviews 49, 158-179.

Rambach, A. \& HoGNESs, D. S. (1977). Translation of Drosophila melanogaster sequences in Escherichia coli. Proceedings of the National Academy of Sciences of the United States of America 74, 5041-5045.

Roberts, R. B., Abelson, P. H., Cowie, D. B., Bolton, E. T. \& BRITTEN, R. J. (1955). Studies of biosynthesis in Escherichia coli. Carnegie Institution of Washington publication no. 607.

SANDERSON, K. E. \& Roth, J. R. (1988). Linkage map of Salmonello typhimurium, edition VII. Microbiological Reviews 52, 485-532.

Shapira, S. K., Chou, J., Richaud, F. V. \& Casadaban, M. J. (1983). New versatile plasmid vectors for expression of hybrid protein coded by a cloned gene fused to $l a c Z$ gene sequences encoding an enzymatically active carboxy-terminal portion of $\beta$-galactosidase. Gene 25, 71-82.

Silhavy, T. J., Berman, M. L. \& ENQUIST, L. W. (1984). Experiments with Gene Fusions. Cold Spring Harbor, NY: Cold Spring Harbor Laboratory.
Smith, C. J., Deutch, A. H. \& Rushlow, K. E. (1984). Purification and characterization of a $\gamma$-glutamyl kinase involved in Escherichia coli proline synthesis. Journal of Bacteriology 157, 545-551.

SOUTHERN, E. (1975). Detection of specific sequences among DNA fragments separated by gel electrophoresis. Journal of Molecular Biology 98, 503-517.

UMBARGER, H. E. (1987). Biosynthesis of the branched-chain aminoacids. In Escherichia coli and Salmonella typhimurium: Cellular and Molecular Biology, pp. 352-367. Edited by F. C. Neidhardt, J. 1. Ingraham, K. B. Low, B. Magasanik, M. Schaechter \& H. E Umbarger. Washington, DC: American Society for Microbiology

Van Eys, G. J. J. M., ZaAl, J., Schoone, G. J. \& Terpstra. W. J. (1988). DNA hybridization with hardjobovis-specific recombinant probes as a method for type discrimination of Leptospira interrogans serovar hardjo. Journal of General Microbiology 134, 567-574.

VieirA, J. \& Messing, J. (1982). The pUC plasmids, an M13mp 7 derived system for insertion mutagenesis and sequencing universal primers. Gene 19, 259-261.

WESTFALL, H. N. (1980). Isoleucine biosynthetic pathways in Leptospira interrogans. PhD thesis. West Virginia University

Westfall, H. N., Charon, N. W. \& Peterson, D. E. (1983). Multiple pathways for isoleucine biosynthesis in the spirochete Leptospira. Journal of Bacteriology 154, 846-853.

Yamaguchi, T., Ono, E. \& Yanagawa. R. (1988). Expression of antigen genes of Leptospira interrogans serovar canicola in Escherichia coli. Microbiology and Immunology 32, 1179-1187

Yelton, D. B. \& ChaRON, N. W. (1984). Cloning of a gene required for tryptophan biosynthesis from Leptospira biflexa serovar patoc into Escherichia coli. Gene 28, 147-152.

Yelton, D. B. \& Cohen, R. A. (1986). Analysis of cloned DNA from Leptospira biflexa serovar patoc which complements a deletion of the Leptospira trpE gene. Journal of Bacteriology 165, 41-46.

Yelton, D. B. \& Peng, S. L. (1989). Identification and nucleotide sequence of the Leptospira biflexa serovar patoc trpE and trpG genes. Journal of Bacteriology 171, 2083-2089.

ZUERNER, R. L. \& BoLIN, C. A. (1988). Repetitive sequence element cloned from Leptospira interrogans serovar hardjo type hardjo-bovis provides a sensitive diagnostic probe for bovine leptospirosis. Journal of Clinical Microbiology 26, 2495-2500.

ZUERnER, R. L. \& ChARON, N. W. (1988). Nucleotide sequence analysis of a gene cloned from Leptospira biflexa serovar patoc which complements an argE defect in Escherichia coli. Journal of Bacteriology 170, 4548-4554. 